unworthy of a chapter in the final history. They will show the need for a better understanding of their potentialities, not only in war-time but also in peace, and for a greater consideration for their permanent upkeep at real efficiency level. For the present, it may be stated that in official circles the services of the Science Library are much appreciated, and they are regarded as indispensable for the conduct of the War.

\section{American Library in Great Britain}

THE U.S. Office of War Information announces the formal opening of the American Library, which has been operating for several months as a special reference library at the American Embassy, 1 Grosvenor Square. The Library is designed for American, British and other United Nations officials, agencies, for research institutions, associations, business, and for the Press. As Mr. Winant said : "This operation represents trust in the free mind and a desire that our Allies be informed on our way of thinking in the United States". The director of the Library, Dr. Richard H. Heindel, said : "By force of war circumstances this might be called a 'utility' or 'austerity' library. We have not consumed vital shipping space. Many of the American books and periodicals are not easily available elsewhere. The experience gained in the library will help us when the time comes to rebuild the libraries and intellectual life of the continent". The American Library Association, the Library of Congress, learned societies and many other American associations, and their opposite numbers in Great Britain, have been consulted constantly in building up this modest but potentially important centre and cultural focus.

\section{The Linnean Society of London}

$\mathrm{Ax}$ the anniversary meeting of the Linnean Society held on May 24, Mr. A. D. Cotton, keeper of the Herbarium in the Royal Botanic Gardens, Kew, was elected president in succession to Dr. E. S. Russell. Dr. Russell addressed the meeting on "The Stereotypy of Instinctive Behaviour". In a review of the activities of the Society, the retiring President directed attention to the revision of the by-laws, just completed; to concession in the amount to be paid by fellows of sixty-five and more who wish to compound; to the fruitful work of the Crustacea Committee and the Marine Algæ Committee; to grants-in-aid towards the cost of publication; to work done by a sub-committee appointed to prepare a plan for rearranging the Library; to the great need for more shelving for the books; to the gratifying progress made towards completing a photographic record of the Linnean collections and manuscripts ; and to the Society's excellent relations with other societies and scientific bodies.

The first fruit of the work of the Sectional Committees, being a key to the British harvestmen or Opiliones by Mr. T. H. Savory, is ready for the printer, as the first of a series of Linnean Society Fauna Synopses. The Marine Algæ Committee's attention has been chiefly directed to collecting data on the ecology of the Fucacer.

The Society has created within itself a new class of members, namely associates, who must be less than thirty years of age and for a yearly subscription of one pound will be admitted to meetings, to the use of the Library and will receive the Proceedings. It is thought that there may be many biologists, such as advanced students, whose means do not permit them to apply for fellowship, but to whom membership of the Linnean Society offers adva] tages, contacts that can ripen into friendships and nspiration.

\section{Message from Chinese Men of Science}

Prof. Tseng Chao-Lun, head of the Department of Chemistry of the National Southwest Associated University, Kunming, China, has sent the following open letter to British scientific men:

"While the introduction of modern science into China dates back to eighty years ago, the real beginnings of scientific research in China came after 1919. On May 4 of that year, students in Peiping (then still called Peking) demonstrated against Japanese agression, and from that incident was evolved the socalled 'May 4th Movement', so important in the cultural as well as the political history of modern China. That movement, which quickly spread all over China, not only rallied the country to the standards of democracy but also promoted the natural sciences as factors in the modernization of China. With this impetus, scientific education and scientific research developed at a rate never dreamed of before. The progress made between 1929 and 1937 was particularly rapid, and constant encouragement was received from scientific workers in the United States and in Europe. Since the outbreak of the SinoJapanese War in 1937, scientific institutions and scientific men in China have suffered tremendously through the deliberate efforts of the Japanese to. destroy Chinese culture. But here in the hinterland of Free China, Chinese men of science have been labouring hard for the last five years in the interest of China and of science.

"Chinese scientific workers owe much to Great Britain for their training. For both democratic ideals and scientific accomplishment, we have always looked to Great Britain for guidance. Now, under the banner of the United Nations, Britain and China are fighting shoulder to shoulder to save democracy for the world; a new era of co-operation between the British and Chinese peoples has begun. Early this year we had the honour of welcoming a cultural mission from the British Council. One of its members is Dr. Joseph Needham, who is now doing most valuable work in our country, and who brought with him a large number of scientific books so much needed by us. Recently, Chinese science students in Britain, with the help of the British Ministry of Information, the British Broadcasting Corporation, the British Council, and other organizations, have started a scheme for sending us science news, which includes a weekly broadcast summary of the principal contents of each week's issue of NATURE; recent valuable scientific publications and microfilm copies are being sent, and scientific books are being collected with the view of establishing an adequate Seience Library in China. Many British men of science are helping in these efforts. We shall never forget such things, and we hope they will develop into a bigger scheme of co-operation between the scientific men of Great Britain and China".

\section{Chance, Freewill and Necessity}

THE twenty-seventh Guthrie Lecture of the Physical Society was delivered on May 18 by Prof. E. T. Whittaker, who took as his subject "Chance, Freewill, and Necessity in the Scientific Conception of the Universe". The lecture was devoted to a study 